\title{
Men's Choice of Contraception Method
}

\author{
Handan Ozcan ${ }^{1}$ (D), Cagla Yigitbas ${ }^{2}$ (D), Mucahit Talha Karaca ${ }^{3}$ (D) \\ ${ }^{1}$ University of Health Sciences, Hamidiye Faculty of Health Sciences, Department of Midwifery, Istanbul, Turkey \\ ${ }^{2}$ Giresun University, Faculty of Health Science, Faculty of Health Sciences, Department of Midwifery, Giresun, Turkey. \\ ${ }^{3}$ Gümüşhane University, Faculty of Health Science, Faculty of Health Sciences, Department of Nursing, Gümüşhane, Turkey. \\ Correspondence Author: Handan Ozcan \\ E-mail: handan.ozcan@sbu.edu.tr
}

Received: 09.07.2020 Accepted: 18.12.2020

\begin{abstract}
Objective: The aim of this study is to examine the contraception choices of men, aged between 18-60 and living in the center of a province in the Gümüşhane.

Methods: The study is of a descriptive type. As a data collection form, an Individual Information Form consisting of a total of 32 questions was used. This form questions the demographic-physical-biological-social-health histories of the participants and their knowledge, attitudes, behaviors about contraception methods. Averages were given together with standard deviations.

Results: $20.8 \%$ of the participants are aged between $26-33$. It was seen that $25.3 \%$ of the participants had knowledge about contraception methods and $64.7 \%$ did not use any methods. When the variables of the age and the marital status are approached in terms of having sufficient knowledge about contraception and still using contraception methods, there is a statistical significance between the variable of 'is the use of contraception methods harmful to health?' with the status of still using contraception methods. A statistical significance is also found between the variable of being sexually active with the status of having sufficient knowledge about contraception and still using contraception methods $(p<0.05)$.

Conclusion: In this study, It has been determined that men who had sufficient information about contraceptions had higher age and higher education levels, were sexually active and married. It has been seen that the age, the marital status, the perception of contraception as harmful to health, the status of being sexually active did not affect receiving any training about contraception.
\end{abstract}

Keywords: Men, contraception method, choice

\section{INTRODUCTION}

The aim of family planning services is to prevent unwanted pregnancies and consequent maternal-infant deaths, to present assistance and counseling services for individuals want to have in any number of children at any time. A good family planning service also includes assistance for couples (infertile) that cannot have children. Another aim of family planning services is to increase the health of maternal-infant. The family planning services also develop the skills of family members in deciding and gives the family the freedom to decide freely about having children. Family planning services are an important part of the "Basic Health Services" that should be offered to the community (1).

Increasing the use of modern family planning methods is one of the primary interventions aimed at improving sexual and reproductive health in developing countries. Reducing unwanted pregnancies is important because of the prevention of sexually transmitted infections such as HIV, the reducing of the maternal-neonatal morbidity and mortality.
The use of family planning methods is one of the critical developmental aims for maternal-infant survival in low - and middle-income countries (2).

Although the number of women seeking to control fertility in underdeveloped countries has increased significantly, there is no proportional increase in modern contraceptive use (3). It has been stated that the reason is the resistance of men to using family planning methods, the problems in reaching the method and in ensuring the continuity. Except that individual decision making, it has been stated that reproductive behaviors are being influenced by social-institutional norms and policies. For this reason, it is insufficient to focus on only women individualistically (2).

Having knowledge about family planning methods is very important both for the decision whether to use a contraceptive method, to decide on which method to use. Staying on top of fertility control is also a rather important step in reaching these methods and using an appropriate contraceptive method (4). 
In many studies, it has been stated that the use of FP methods is influenced by many factors such as education level of the woman and her spouse, number of children, ideal family size, spouses' decisions, ideal birth interval, men's perspective to FP. It also has been expressed that the participation of men to this process should be ensured in order to achieve the desired success in FP services $(5,6)$. The number of studies with men related to the family planning process is few. This study was planned to determine the family planning methods used bymen, the reasons for using these methods, the factors affecting men.

\section{METHODS}

\subsection{Type of research}

This study is of a descriptive type.

\subsection{Population of the research and selection of sample}

The population of the study has been consisting of males, aged between 18-60, living in the center of Gümüşhane province. According to the 2017 year address-based population registration system, the number of males in this age range is 18303 . After the calculations, minimum 377 people were planned to be included in the sample at a $95 \%$ confidence interval. However, it was aimed to reach 400 people (approximately $10 \%$ of the sample calculated against the probability of possible loss has been reached) in the study considering the possible losses. The sample group was reached according to the improbable sampling method. Participants were divided into 8-year age groups. Thus, 5 groups were formed. Men with cognitive or mental disability and illiterate were excluded from the study. Also, verbal consent was obtained from the participants. Data were collected by face-to-face interviews with participants who voluntarily agreed to participate in the study. Data of the study were collected during a 3-month period.

\subsection{Data collection}

In the study, an Individual Information Form consisting of a total of 32 questions and developed in accordance with literature by researchers was used. This form, which used as a data collection tool, questions the demographic-physical-biologicalsocial-health histories of the participants and their knowledge, attitudes, behaviors about contraception methods.

The independent variables of the study are the demographicphysical-biological-social data of the participants. The dependent variables are health histories of the participants and their knowledge, attitudes, behaviors about the contraception methods.

\subsection{Ethical considerations}

The required permission to conduct the study was obtained from the administration unit of the Health Directorate and from the Scientific Research and Publication Board of Gümüşhane University (Number= 95674917-604.01.02E.831, Approval Date= 08.01.2018).

\subsection{Statistical analysis}

The statistical package program was used for analysis. Error checks and tables were made through this program. Number and percentage distributions were made in the meta-data; 'chi-suare' and 'fisher's exact test-2-sided' tests were used for data analysis. Averages were given together with standard deviations. $p<0.05$ was considered significant.

\section{RESULTS}

$20.8 \%$ of the participants are aged between $26-33.53 .7 \%$ have an education above the high school level. $59.3 \%$ are married. $35 \%$ do not work. The rate of the participants with a high income is $16 \%$. The average number of children (min: 1 ; max: 6 ) is 2.68 (Table 1). The sources of information about sexuality were asked to the participants. $24 \%$ of the participants stated that obtained information from friends, $37.5 \%$ from the internet, $5.8 \%$ from books, $4.8 \%$ from newspapers, $2 \%$ from magazines, $4.8 \%$ from their family, the rest from several sources.

Table 1. Socio-demographic characteristics of participants $(N=400)$ Socio-Demographic Characteristics $n \quad \%$ Age

Between 18-25

Between 26-33

Between 34-41

Between 42-50

$80 \quad 20.0$

Between 50-60

$83 \quad 20.8$

Education Status

Primary school

Secondary school

High school

Associate degree

College/faculty

Marital Status

$\begin{array}{lll}\text { Married } & 237 & 59.2\end{array}$

Single $163 \quad 40.8$

Occupation status

Educator

Security staff

Medical staff

Craft

Worker

Official $79 \quad 19.8$

$\begin{array}{ll}78 & 19.4\end{array}$

$80 \quad 20.0$

Jobless $34 \quad 8.5$

$49 \quad 12.3$

$102 \quad 25.5$

$66 \quad 16.5$

$\begin{array}{cc}66 & 16.5 \\ 149 & 37.2\end{array}$

\section{Income Status}

$\begin{array}{lll}\text { Income is less than expense } & 132 \quad 33.0\end{array}$

Income is equal to expense $\quad 204 \quad 51.0$

Income is more than expense $\quad 64 \quad 16.0$

\section{Smoking Status}

Yes

$\begin{array}{lll}214 & 53.5 \\ -186 & 46.5\end{array}$

The status of being sexually active

\begin{tabular}{lll} 
Yes & $263 \quad 65.8$ \\
\hline
\end{tabular}

No

$137 \quad 34.2$

The status of getting a sexually transmitted disease Yes No 
The awareness and practices of the men participating in the study related to contraception methods are approached in Table 2.

Table 2. The awareness and practices of the participants related to contraception methods $(N=400)$

\begin{tabular}{lll} 
Features & $\mathbf{n}$ & $\%$ \\
\hline The status of receiving any training about contraception & & \\
Yes & 101 & 25.2 \\
No & 299 & 74.7 \\
\hline The status of having sufficient & information & about \\
contraception & 220 & 55.0 \\
Yes & 180 & 45.0 \\
No & & \\
\hline The heard contraception method & & \\
Condom (Cover, preservative) & 217 & 54.3 \\
Contraceptive pills & 40 & 10.0 \\
Intrauterine device (spiral) & 20 & 5.0 \\
Injection method & 7 & 1.8 \\
Post-tube legation & 10 & 2.5 \\
Vasectomy & 7 & 1.8 \\
Subcutaneous implants & 3 & 0.8 \\
Coitus interruptus & 53 & 13.3 \\
Rhythm method & 12 & 3.0 \\
Spermicidal & 1 & 0.3 \\
Emergency contraceptive methods & 6 & 1.5 \\
Other & 17 & 4.3 \\
All & 7 & 1.8 \\
\hline The status of using any contraception method & & \\
Yes & 141 & 35.3 \\
No & 259 & 64.7 \\
\hline The & & \\
\hline
\end{tabular}

\begin{tabular}{lll}
\hline The used contraception method & & \\
Condom (Cover, preservative) & 92 & 64.3 \\
Contraceptive pills & 13 & 9.1 \\
Intrauterine device (spiral) & 9 & 6.3 \\
Post-tube legation/Vasectomy & 1 & 0.7 \\
Subcutaneous implants & 1 & 0.7 \\
Coitus interruptus & 17 & 11.9 \\
Rhythm method & 1 & 0.7 \\
Other & 7 & 6.3 \\
Total & 141 & 100.0 \\
\hline The status of using and quitting any contraception & \\
method & 11 & 2.8 \\
Yes & 389 & 97.2 \\
No & & \\
\hline Reason for choosing the current method (n=140) & & \\
For finding it safe & 74 & 52.9 \\
Because it is convenient & 39 & 27.9 \\
I only know this method & 10 & 7.1 \\
Easy to use & 9 & 6.4 \\
Other & 8 & 5.7 \\
\hline Reason for not using any contraception method (n=264) & \\
No need & 144 & 54.5 \\
Lack of regular and frequent sexual intercourse & 33 & 12.5 \\
Don't think your partner will get pregnant & 9 & 3.4 \\
Disbelief contraceptive & 12 & 4.5 \\
Finding contrary to my beliefs & 20 & 7.6 \\
Not having enough information about family planning & 31 & 11.8 \\
Other & 15 & 5.7 \\
\hline & & \\
\hline
\end{tabular}

\begin{tabular}{|c|c|c|}
\hline \multicolumn{3}{|c|}{ The status of experiencing an unwanted pregnancy } \\
\hline Yes & 42 & 10.5 \\
\hline No & 358 & 89.5 \\
\hline \multicolumn{3}{|c|}{ The status of affecting sexuality of family planning } \\
\hline Yes & 140 & 35.0 \\
\hline \multicolumn{3}{|l|}{ No } \\
\hline \multicolumn{3}{|l|}{ 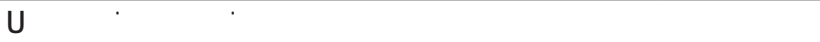 } \\
\hline Condom (Cover, preservative) & 119 & 45.2 \\
\hline Contraceptive pills & 41 & 15.6 \\
\hline Intrauterine device (spiral) & 30 & 11.4 \\
\hline Injection method & 8 & 3.0 \\
\hline Post-tube legation & 6 & 2.3 \\
\hline Vasectomy & 11 & 4.2 \\
\hline Subcutaneous implants & 5 & 1.9 \\
\hline Coitus interruptus & 33 & 12.5 \\
\hline Rhythm method & 4 & 1.5 \\
\hline Spermicidal & 3 & 1.1 \\
\hline Emergency contraceptive methods & 3 & 1.1 \\
\hline Total & 263 & 100.0 \\
\hline
\end{tabular}

In the study, it has been seen that $25.3 \%$ of the participants had knowledge about contraception methods and 55\% of the participants thought that had enough information about contraception methods (Table 2).

In the study, participants were asked what understood from contraception. $20 \%$ of the participants stated that contraception was to have a limited number of children, $12 \%$ to have children when spouses want, $12.3 \%$ to limit the number of member in the family, $51 \%$ to have enough number of children to be supported and raised, $1.8 \%$ to educate the individuals and families about reproductive health, $0.8 \%$ to prevent maternal deaths and save their healths, $0.3 \%$ to provide medical help to individuals who want to have children, $1.3 \%$ to prevent high-risk and unwanted pregnancies, $0.8 \%$ to neuter the individuals.

In this study, $54.3 \%$ of the participants said condom/ bonnet/sheath/preservative in response to the question of which contraception method heard by. Participants were asked who should be given the family planning method. $89 \%$ of participants said that the family planning method should be given to both sexes, $7.5 \%$ to just women, $3.5 \%$ to just men.

In the answer to the question of where contraception methods can be obtained, pharmacies (38\%), community health centers $(18 \%)$, hospitals $(16.5 \%)$, centers of maternal and child health (12.3\%), private health institutions $(8.8 \%)$, other places (6.5\%) took place respectively. As seen in Table $2,64.7 \%$ of the participants do not use any contraception methods (Table 2).

$32.9 \%$ of the participants prefer the traditional methods and the rest $(67.1 \%)$ prefer the modern methods. At the same time, $2.8 \%$ of the participants aren't using any method now, although had used any contraception method before. 
Table 3. According to the socio-demographic characteristics of the participants; the statuses of receiving any training about any contraception methods, having sufficient knowledge, using any contraception methods, using and quitting these methods $(N=400)$ *

\begin{tabular}{|c|c|c|c|c|c|c|c|c|c|}
\hline \multirow[t]{2}{*}{ Socio-Demographic Characteristics } & \multirow[t]{2}{*}{ n } & \multicolumn{2}{|c|}{$\begin{array}{l}\text { The status of receiving } \\
\text { training about } \\
\text { contraception }\end{array}$} & \multicolumn{2}{|c|}{$\begin{array}{l}\text { The status of having } \\
\text { sufficient information } \\
\text { about contraception }\end{array}$} & \multicolumn{2}{|c|}{$\begin{array}{l}\text { The status of still using } \\
\text { contraception methods }\end{array}$} & \multicolumn{2}{|c|}{$\begin{array}{l}\text { The status of using and } \\
\text { quitting contraception } \\
\text { method }\end{array}$} \\
\hline & & $\begin{array}{c}\text { Yes } \\
n(\%)\end{array}$ & $\begin{array}{l}\text { No } \\
n(\%)\end{array}$ & $\begin{array}{l}\text { Yes } \\
\mathrm{n}(\%)\end{array}$ & $\begin{array}{l}\text { No } \\
n(\%)\end{array}$ & $\begin{array}{l}\text { Yes } \\
\mathrm{n}(\%)\end{array}$ & $\begin{array}{l}\text { No } \\
n(\%)\end{array}$ & $\begin{array}{l}\text { Yes } \\
n(\%)\end{array}$ & $\begin{array}{c}\text { No } \\
n(\%)\end{array}$ \\
\hline \multicolumn{10}{|l|}{ Age } \\
\hline Between 18-25 & 80 & $19(23.8)$ & $61(76.2)$ & $24(30.0)$ & $56(70.0)$ & $13(16.3)$ & $67(83.8)$ & $1(1.3)$ & $79(98.8)$ \\
\hline Between 26-33 & 83 & $30(36.1)$ & $53(63.9)$ & $52(62.7)$ & $31(37.3)$ & $29(34.9)$ & $54(65.1)$ & $1(1.3)$ & $82(98.8)$ \\
\hline Between 34-41 & 79 & $20(25.3)$ & $59(74.7)$ & $49(62.0)$ & $30(38.0)$ & $35(44.3)$ & $44(55.7)$ & $3(3.8)$ & $76(96.2)$ \\
\hline Between 42-50 & 78 & $18(23.1)$ & $60(76.9)$ & $45(57.7)$ & $33(42.3)$ & $39(50.6)$ & $38(49.4)$ & $2(2.6)$ & $76(97.4)$ \\
\hline \multirow[t]{2}{*}{ Between $50-60$} & 80 & $14(17.5)$ & $66(82.5)$ & $50(62.5)$ & $30(37.5)$ & $25(31.3)$ & $55(68.8)$ & $4(5.0)$ & $76(95.0)$ \\
\hline & Test Value & \multicolumn{2}{|c|}{$\chi^{2}=8.05 s d=4 p=0.09$} & \multicolumn{2}{|c|}{$\chi^{2}=25.78 s d=4 p=0.000$} & \multicolumn{2}{|c|}{$\chi^{2}=24.02 \mathrm{sd}=4 \mathrm{p}=0.000$} & \multicolumn{2}{|c|}{$\chi^{2}=3.26 s d=4 p=0.515$} \\
\hline \multicolumn{10}{|l|}{ Education Status } \\
\hline Primary school & 34 & $2(5.9)$ & $32(94.1)$ & $12(35.3)$ & $22(64.7)$ & $10(30.3)$ & $23(69.7 ?$ & $0(0.0)$ & $34(100.0)$ \\
\hline Secondary school & 49 & $7(14.3)$ & $42(85.7)$ & $26(53.1)$ & $23(46.9)$ & $15(30.6)$ & $34(69.4)$ & $2(4.1)$ & $47(95.9)$ \\
\hline High school & 102 & $22(21.6)$ & $80(78.4)$ & $67(65.7)$ & $35(34.3)$ & $48(47.1)$ & $54(52.9)$ & $4(3.9)$ & $98(96.1)$ \\
\hline Associate degree & 66 & $23(34.8)$ & $43(65.2)$ & $44(66.7)$ & $22(33.3)$ & $22(33.3)$ & $44(66.7)$ & $0(0.0)$ & $66(100.0)$ \\
\hline College/faculty & 145 & $46(31.7)$ & $99(68.3)$ & $68(46.9)$ & $77(53.1)$ & $45(31.0)$ & $100(69.0)$ & $4(2.8)$ & $141(97.2)$ \\
\hline \multirow[t]{2}{*}{ Master } & 4 & $1(25.0)$ & $3(75.0)$ & $3(75.0)$ & $1(25.0)$ & $1(25.0)$ & $3(75.0)$ & $1(25.0)$ & $3(75.0)$ \\
\hline & Test Value & \multicolumn{2}{|c|}{$\chi^{2}=17.05 s d=5 p=0.004$} & \multicolumn{2}{|c|}{$\chi^{2}=18.23 s d=5 p=0.003$} & \multicolumn{2}{|c|}{$\chi^{2}=8.45 s d=5 p=0.133$} & \multicolumn{2}{|c|}{$\chi^{2}=11.08 s d=5 p=0.050$} \\
\hline \multicolumn{10}{|l|}{ Marital Status } \\
\hline Married & 237 & $56(23.6)$ & $181(76.4)$ & $151(63.7)$ & $86(36.3)$ & $106(44.9)$ & $130(55.1)$ & $9(3.8)$ & $228(96.2)$ \\
\hline \multirow[t]{2}{*}{ Single } & 163 & $45(27.6)$ & $118(72.4)$ & $69(42.3)$ & $94(57.7)$ & $35(21.5)$ & $128(78.5)$ & $2(1.2)$ & $161(98.8)$ \\
\hline & Test Value & \multicolumn{2}{|c|}{$\chi^{2}=0.81 \mathrm{sd}=1 \mathrm{p}=0.368$} & \multicolumn{2}{|c|}{$\chi^{2}=17.84 s d=1 p=0.000$} & \multicolumn{2}{|c|}{$\chi^{2}=23.18 s d=1 p=0.000$} & \multicolumn{2}{|c|}{$\chi^{2}=2.38 s d=1 p=0.122$} \\
\hline \multicolumn{10}{|l|}{ Income Status } \\
\hline Income is less than expense & 132 & $23(17.4)$ & $109(82.6)$ & $65(49.2)$ & $67(50.8)$ & $43(32.8)$ & $88(67.2)$ & $2(1.5)$ & $130(98.5)$ \\
\hline Income is equal to expense & 204 & $49(24.0)$ & $155(76.0)$ & $115(56.4)$ & $89(43.6)$ & $73(35.8)$ & $131(64.2)$ & $7(3.4)$ & $197(96.6)$ \\
\hline \multirow[t]{2}{*}{ Income is more than expense } & 64 & $29(45.3)$ & $35(54.7)$ & $40(62.5)$ & $24(37.5)$ & $25(39.1)$ & $39(60.9)$ & $2(3.1)$ & $62(96.9)$ \\
\hline & Test Value & \multicolumn{2}{|c|}{$\chi^{2}=18.09 \mathrm{sd}=2 p=0.000$} & \multicolumn{2}{|c|}{$\chi^{2}=3.37 s d=2 p=0.185$} & \multicolumn{2}{|c|}{$\chi^{2}=0.76 s d=2 p=0.681$} & \multicolumn{2}{|c|}{$\chi^{2}=1.14 s d=2 p=0.565$} \\
\hline
\end{tabular}

Should contraception be given as

education in schools?

\begin{tabular}{|c|c|c|c|c|c|c|c|c|c|}
\hline Yes & 222 & $70(31.5)$ & $152(68.5)$ & $123(55.4)$ & $99(44.6)$ & $76(34.2)$ & $146(65.8)$ & $9(4.1)$ & 213 (95.9) \\
\hline No & 98 & $15(15.3)$ & $83(84.7)$ & $58(59.2)$ & $40(40.8)$ & $37(37.8)$ & $61(62.2)$ & $2(2.0)$ & $96(98.0)$ \\
\hline Undecided & 80 & $16(20.0)$ & $64(80.0)$ & $39(48.8)$ & $41(51.3)$ & $28(35.4)$ & $51(64.6)$ & $0(0.0)$ & $80(100.0)$ \\
\hline & Test Value & \multicolumn{2}{|c|}{$\chi^{2}=10.94 \mathrm{sd}=2 \mathrm{p}=0.004$} & \multicolumn{2}{|c|}{$\chi^{2}=1.97 s d=2 p=0.373$} & \multicolumn{2}{|c|}{$\chi^{2}=0.36 s d=2 p=0.831$} & \multicolumn{2}{|c|}{$\chi^{2}=3.35 s d=2 p=0.145$} \\
\hline \multicolumn{10}{|c|}{$\begin{array}{l}\text { Is the use of contraception } \\
\text { methods harmful to health? }\end{array}$} \\
\hline Yes & 79 & $18(22.8)$ & $61(77.2)$ & $53(67.1)$ & $26(32.9)$ & $35(44.3)$ & $44(55.7)$ & $1(1.3)$ & $78(98.7)$ \\
\hline \multirow[t]{2}{*}{ No } & 321 & $83(25.9)$ & $238(74.1)$ & $167(52.0)$ & $154(48.0)$ & $106(33.1)$ & 214 (66.9) & $10(3.1)$ & 311 (96.9) \\
\hline & Test Value & \multicolumn{2}{|c|}{$\chi^{2}=0.31 \mathrm{sd}=1 \mathrm{p}=0.573$} & \multicolumn{2}{|c|}{$\chi^{2}=5.81 \mathrm{sd}=1 \mathrm{p}=0.016$} & \multicolumn{2}{|c|}{$\chi^{2}=3.46 s d=1 p=0.063$} & \multicolumn{2}{|c|}{$\chi^{2}=0.81 \mathrm{sd}=1 \mathrm{p}=0.368$} \\
\hline \multicolumn{10}{|c|}{ The status of being sexually active } \\
\hline Yes & 263 & $72(27.4)$ & $191(72.6)$ & $158(60.1)$ & $105(39.9)$ & 115 (43.9) & $147(56.1)$ & $7(2.7)$ & $256(97.3)$ \\
\hline \multirow[t]{2}{*}{ No } & 137 & $29(21.2)$ & $108(78.8)$ & $62(45.3)$ & $75(54.7)$ & $26(19.0)$ & $111(81.0)$ & $256(97.3)$ & $133(97.1)$ \\
\hline & Test Value & \multicolumn{2}{|c|}{$\chi^{2}=1.84 s d=1 p=0.175$} & \multicolumn{2}{|c|}{$\chi^{2}=7.99 \mathrm{sd}=1 \mathrm{p}=0.005$} & \multicolumn{2}{|c|}{$\chi^{2}=24.43 \mathrm{sd}=1 \mathrm{p}=0.000$} & \multicolumn{2}{|c|}{$\chi^{2}=0.02 s d=1 p=0.881$} \\
\hline \multicolumn{10}{|c|}{$\begin{array}{l}\text { The status of experiencing an } \\
\text { unwanted pregnancy }\end{array}$} \\
\hline Yes & 42 & $8(19.0)$ & $34(81.0)$ & $27(64.3)$ & $15(35.7)$ & $18(42.9)$ & $24(57.1)$ & $3(7.1)$ & $39(92.9)$ \\
\hline \multirow[t]{2}{*}{ No } & 358 & $93(26.0)$ & $265(74.0)$ & $193(53.9)$ & $165(46.1)$ & $123(34.5)$ & $234(65.5)$ & $8(2.2)$ & $350(97.8)$ \\
\hline & Test Value & \multicolumn{2}{|c|}{$\chi^{2}=0.95 s d=1 p=0.328$} & \multicolumn{2}{|c|}{$\chi^{2}=1.63 \mathrm{sd}=1 \mathrm{p}=0.201$} & \multicolumn{2}{|c|}{$\chi^{2}=1.16 s d=1 p=0.281$} & \multicolumn{2}{|c|}{$\chi^{2}=3.38 s d=1 p=0.066$} \\
\hline \multicolumn{10}{|c|}{$\begin{array}{l}\text { Is abortion a } \\
\text { contraception } \\
\text { method? }\end{array}$} \\
\hline Yes & 65 & $16(24.6)$ & $49(75.4)$ & $40(61.5)$ & $25(38.5)$ & $25(38.5)$ & $40(61.5)$ & $0(0.0)$ & $65(100.0)$ \\
\hline \multirow{2}{*}{ No } & 335 & $85(25.4)$ & $250(74.6)$ & $180(53.7)$ & $155(46.3)$ & $116(34.7)$ & $218(65.3)$ & $11(3.3)$ & $324(97.3)$ \\
\hline & Test Value & \multicolumn{2}{|c|}{$\chi^{2}=0.01 \mathrm{sd}=1 \mathrm{p}=0.898$} & \multicolumn{2}{|c|}{$\chi^{2}=1.34 \mathrm{sd}=1 \mathrm{p}=0.24$} & \multicolumn{2}{|c|}{$\chi^{2}=0.33 s d=1 p=0.56$} & \multicolumn{2}{|c|}{$\chi^{2}=2.19 \mathrm{sd}=1 \mathrm{p}=0.138$} \\
\hline
\end{tabular}

* Rows percentage is taken 
It has seen that when the participants were asked why preferred that methods, finding it safe (52.9\%) was placed on the top; when the participants were asked the reason for not using any contraception method, finding unnecessary (54.5\%) was placed on the top. In the study, the status of experiencing an unwanted pregnancy was determined as $10.5 \%$. The most common methods used by participants were the use of condoms (64.3\%), the method of coitus interruptus (11.9\%), the use of contraceptive pills (9.1\%). $65 \%$ of the participants stated that using contraception affects sexual life. The most common method affecting sexual life is condom with $45.2 \%$. This is followed by the use of contraceptive pills, the method of coitus interruptus the intrauterine device usage (Table 2).

As the FP method which is effective in protecting from sexually transmitted infections (STI), $81 \%$ of the participants said condoms, $4.8 \%$ contraceptive pills, the rest intrauterine device (IUD), the method of coitus interruptus, tubal ligation.

Finally, the participants were asked how to look at education in schools about contraception methods. It was determined that $55.5 \%$ of the participants approved, $24.5 \%$ did not approve, the rest (20\%) hesitant. On the other hand, $19.8 \%$ of the participants stated that the use of contraception methods is harmful to health.

As it is seen in Table 3, cross-tables were made between some socio-demographic characteristics and approaches to contraception of the participants with the statuses of receiving any training about contraception methods, having sufficient information, using any contraception methods, using and quitting contraception methods. Hereunder;

Between the variable of the age with the status of having sufficient information about contraception and the status of still using contraception method,

Between the variable of the education level with the statuses of receiving any training about contraception, having sufficient information about contraception, using and quitting contraception methods,

Between the variable of the marital status with the status of having sufficient information about contraception and the status of still using contraception methods,

Between the variable of the income level with the status of receiving any training about contraception,

Between the variable of 'should the subject of contraception be given as education in schools?' with the status of receiving any training about contraception,

Between the variable of 'is the use of contraception methods harmful to health?' with the status of still using contraception methods,

Between the variable of being sexually active with the status of having sufficient information about contraception and the status of still using contraception methods,

Statistical significance was found between all these data $(p<$ 0.05).

\section{DISCUSSION}

In this study, the family planning methods used by men, the reasons for using these methods, the factors affecting men were determined. $20.8 \%$ of men participating from Gümüşhane (a province in the Black Sea Region) are aged between $26-33$. $53.7 \%$ of men have an education above the high school level.

Participants of the research have various sources of information about sexuality and family planning. These are respectively internet (37.5\%), friends (24\%), books $(5.8 \%)$, newspapers (4.8\%), family (4.8\%) and magazines (2\%). In the study in which the information statuses of men in Uganda about family planning was questioned, it was stated that there were various sources of information such as peers, health care personnel, mass communication, partners. The percentages of education received from health care personnel and mass communication campaigns were lower than other sources of information (7).

According to men participated in the study, the contraception is to have a limited number of children, to have children when spouses want, to limit the number of member in the family, to have enough number of children to be supported and raised, to educate individuals and families about reproductive health, to prevent maternal deaths and save healths, to prevent high-risk and unwanted pregnancies.

In a study, the reasons for using a small number of contraceptive methods of young people include cancer, fibroids, reproductive morbidity and fear of infertility for their female partners (8). In another study, it has been shown that the reasons of men for not using the hormonal contraceptives used by their spouses include the excessive bleeding, the menstrual irregularity, the concerns about reducing sexual desire among women (9).

$67.1 \%$ of the participants prefer modern methods and $32.9 \%$ use traditional methods. In this study, the most common contraception method known by participants is the use of a condom (54.3\%). The use of contraceptive pills and the method of coitus interruptus follow this. In the study, the large majority of the participants (89\%) stated that information about family planning methods should be given to both sexes. In Asian countries such as Pakistan, it is stated that very few men use contraception methods and are generally resistant to the use of modern methods (10). In the researches based on society and population, it was emphasized that it is important to increase the deciding power of women due to their spouses' resistance to contraception (11). For example, according to the Pakistan Demographic Health Survey data (2013), it has been stated that the most commonly used methods were the use of a condom (9\%) and the method of coitus interruptus (8.5\%) (12). According to 2013 TDHS data, $33 \%$ of women and $47 \%$ of currently married women used a modern method, while $18 \%$ of women and $26 \%$ of currently married women used a traditional method. The method of coitus interruptus used by one in four married women (26\%) is the most common method of contraception. IUD (17\%) is 
the most used modern method by married women. The most common method after IUD is the male condom (16\%). Health experts emphasized that the use of condoms can be used not only against sexually transmitted infections but also as an alternative method when the use of hormonal contraceptive is not appropriate (13).

It has seen that when men were asked why preferred that methods now, finding it safe (52.9\%) was placed on the top; when the participants were asked the reason for not using any contraception method, finding unnecessary (54.5\%) was placed on the top. In the study, $65 \%$ of the participants stated that using contraception affects sexual life. The status of experiencing an unwanted pregnancy was determined as $10.5 \%$.

It was determined that $55.5 \%$ of the participants approved the education in schools about contraception methods. On the other hand, $19.8 \%$ of the participants stated that the use of contraception methods was harmful to health. In the meetings, it was stated that family planning services and training provided by health experts were safe at the level of evidence. After appropriate counseling, problems such as failure in the use of contraception methods and unwanted pregnancies are being prevented. The counseling over decreasing fertility associated with the increasing age of women includes the creation of appropriate policies (13).

Women in society have primarily responsible for raising children. Therefore, especially in patriarchal societies, it is important for women to be a decision-maker on the choice of contraception together with men. It has been indicated that in Canada, all methods including abortion should be easily accessible for individuals without taking into account their geographical location. For this; taking the history, screening contraindications, dispensing the method, prescribing, selecting, sexual behaviors of individuals, reproductive health risks, social conditions, belief systems, evaluating of the cultural and political structures, improving the use skills related to the method should be necessary (13).

Sexually transmitted diseases are very important problem today. The use of 'condom', one of the modern methods of family planning, has an important place in the fight against this problem. However, in order to ensure the participation of men in family planning services and works, there are other approaches in addition to popularize the methods that can be used by men. In these approaches, men are expected to be active in all family planning services. In other words, it is emphasized that men should act together with women in deciding the use, the choice, the follow-up of the family planning method and also it is known that social positions of men and women are important in this regard (13).
It is important to include men in family planning practices, to increase modern family planning methods, to plan training for both sexes, to receive necessary training from health experts.

\section{REFERENCES}

[1] Kaya H, Tatlı H, Açık Y, Deveci E. Bingöl ili uydukent sağlık ocağı bölgesindeki 15-49 yaş kadınların aile planlaması yöntemi kullanım düzeyinin belirlenmesi. FÜ Sağ Bil Derg 2008; 22(4):185-191. (Turkish)

[2] Adanikin Al, McGrath N, Padmadas S. Impact of men's perception on family planning demand and uptake in Nigeria. Sexual \& Reproductive Healthcare 2017; 14:55-63.

[3] Darroch JE, Singh S. Trends in contraceptive need and use in developing countries in 2003, 2008, and 2012: an analysis of national surveys. Lancet 2013; 381(9879):1756-62.

[4] Türkiye Nüfus ve Sağlık Araştırması, Hacettepe Üniversitesi Nüfus Etütleri Enstitüsü Ankara, Türkiye, 2013. (Turkish)

[5] Kitiş Y, Bilgili N, Karaçam Z. Gülveren sağlık ocağı bölgesinde yaşayan erkeklerin aile planlamasına ılişkin görüşleri ve karara katılma durumları. Sağlık ve Toplum 2004; 14(1):56-66. (Turkish)

[6] Altay B, Gönener D. Evli Erkeklerin Aile Planlaması Yöntemlerini Bilme ve Kullanma Durumları ve Etkileyen Faktörler. Fırat Tıp Dergisi 2009; 14(1):56-64. (Turkish)

[7] Thummalachetty N, Mathur S, Mullinax M. Contraceptive knowledge, perceptions, and concerns among men in Uganda. BMC Public Health 2017; 17:792.

[8] Nalwadda G, Mirembe F, Byamugisha J, Faxelid E. Persistent high fertility in Uganda: young people recount obstacles and enabling factors to use of contraceptives. BMC Public Health 2010; 10:530.

[9] Hyttel M, Rasanathan JJ, Tellier M, Taremwa W. Use of injectable hormonal contraceptives: diverging perspectives of women and men, service providers and policymakers in Uganda. Reprod Health Matters 2012; 20:148-57.

[10] Zaidi B, Hussain S. Reasons for Low Contraceptive Use Insights from Pakistan and Neighbouring Countries. Islamabad: Population Council, 2015.

[11] Rizvi N, Khan K, Shaikh B. Gender: Shaping Personality, Lives, and Health of Women in Pakistan. BMC Women's Health 2014; 14(53):1-8.

[12] Brown E, Gul X, Abbas A, Nasar A, Balal A. Men's perceptions of child-bearing and fertility control in Pakistan: insights from a PEER Project. Culture, Health \& Sexuality 2017; 19(11):12251238.

[13] Black A, Guilbert E, et al. Canadian Contraception Consensus. J Obstet Gynaecol Can, 2015; 37(10):936-938

[14] Akın L, Özaydın N, Aslan D. Türkiye'de evli erkeklerin aile planlaması yöntemlerini kullanmalarını etkileyen faktörler. Gülhane Tıp Dergisi 2006; 48:63-69 (Turkish). 